
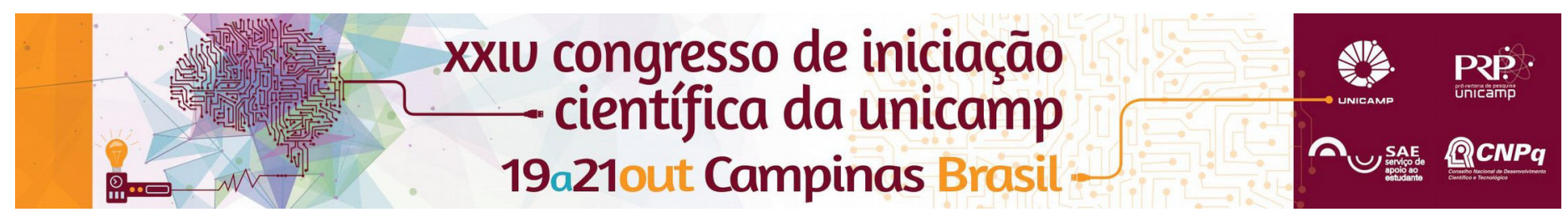

\title{
O sucesso de Eugène Labiche no Rio de Janeiro, de 1840 a 1890
}

\author{
Isabela Battibugli*, Orna Messer Levin
}

\begin{abstract}
Resumo
A grande recorrência de encenações de peças do dramaturgo francês Eugène Labiche (1815-1888) durante o século XIX constitui um fenômeno transnacional que merece atenção. Este trabalho se propõe a fazer um estudo sobre a presença de sua dramaturgia no Rio de Janeiro, tanto em francês quanto em português, entre os anos 1840 e 1890 . A análise dos espetáculos montados na capital do império brasileiro nos permite compreender melhor o processo de transferência cultural e de difusão do repertório teatral francês no Brasil.
\end{abstract}

\section{Palavras-chave:}

Eugène Labiche, teatro, repertório cômico

\section{Introdução}

A hegemonia de referências francesas foi uma das coisas que mais marcou o processo de globalização da cultura no século XIX. O teatro, por alcançar pessoas de todas as classes sociais, era um dos maiores meios de disseminação de ideias. Eugène Labiche foi um dramaturgo francês muito encenado no Rio de Janeiro que se insere neste processo de transferência cultural. Este autor alcançou grande sucesso com suas peças cômicas, tanto na França quanto no Brasil. Foram recolhidas informações sobre as encenações de suas peças no Rio de Janeiro, entre os anos de 1840 e 1890. Foram consideradas tanto as obras encenadas em francês quanto as representadas em português.

\section{Resultados e Discussão}

Segundo a metodologia do projeto temático "A Circulação Transatlântica dos Impressos - A Globalização da Cultura no Século XIX", foram feitas pesquisas nos maiores periódicos da época para se construir um panorama amplo de contexto. Os anúncios de encenações no Rio de Janeiro foram levantados e cadastrados no banco de dados (CITRIM) deste projeto temático. Nos jornais utilizados como fontes primárias, pesquisou-se principalmente os agentes de transferência cultural, como tradutores, críticos e diretores de companhias artísticas. Identificar estas pessoas é de suma importância para se pensar a internacionalização da cultura francesa naquele século.

A partir desta pesquisa na imprensa diária fluminense, é bastante claro que as comédias de Eugène Labiche eram largamente apreciadas pelo público dos teatros da cidade do Rio de Janeiro, sendo encenadas tanto em francês quanto em português. Companhias dramáticas francesas traziam muitas obras deste autor para o Brasil em seus repertórios. Por exemplo, pode-se citar a Compagnie Lyrique Française na década de 1840, a Companhia de J. Arnaud em 1860 e a de A. Malet na década de 1870. Sobre as encenações em português, encontram-se traduções livres de autores anônimos e de grandes nomes da época, como Arthur Azevedo, Moreira Sampaio e Eduardo Garrido.

Além disso, por vezes, suas peças sofriam um tipo muito característico de apropriação cultural - a adaptação de peças francesas para a "cena brasileira" -, que consistia em trocar os elementos tipicamente franceses por outros que fossem característicos do Brasil. A peça Le choix d'un gendre, por exemplo, foi "acomodada à cena brasileira" pelo grande escritor brasileiro Artur Azevedo, recebendo o título Genro e sogro.

É importante notar que o nome de Labiche aparecia sempre indicado com destaque nos anúncios dos espetáculos. Seu prestígio como um dos melhores autores cômicos da época era utilizado para atrair o público fluminense ao teatro. Isso é ainda mais importante quando se considera que a grande maioria de suas peças foi composta em conjunto com outros escritores, cujos nomes raramente são mencionados.

A análise dos anúncios compilados mostrou que as obras de Labiche alcançaram um sucesso enorme, ficando em cartaz por bastante tempo. Algumas peças se repetiam e poderiam ser vistas em várias casas de espetáculo ao longo dos anos. Para exemplificar sua longevidade nos palcos brasileiros, pode-se citar a peça Un garçon de chez Véry. Esta peça cômica foi encenada no Rio de Janeiro em duas ocasiões e em circunstâncias bastante diferentes: a primeira em julho de 1851, no Teatro São Januário, em francês; e a segunda, ao longo dos seis primeiros meses de 1880, no Teatro Ginásio, em uma tradução para o vernáculo.

\section{Conclusão}

O fato de existirem, no Rio de Janeiro, recorrentes encenações de peças deste grande comediógrafo mostra que Labiche foi um autor de sucesso internacional. O fato de sua obra ser encenada tanto em sua língua original quanto em versões traduzidas para o português (sendo estas feitas pouco depois da estreia em Paris) mostra também que suas comédias garantiam bilheteria. Assim, percebe-se que as peças de Labiche eram extremamente bem recebidas pelo público brasileiro, já que contam com um número de encenações bastante expressivo.

\section{Agradecimentos}

FAPESP - Fundação de Amparo à Pesquisa do Estado de São Paulo. 